\title{
THE INFLUENCE OF PRESENCE OF CADMIUM AND ARSENIC IN FEEDMEAL ON PRODUCTION AND REPRODUCTION TRAITS OF GOATS ${ }^{* *}$
}

\author{
N. Memiši ${ }^{1^{*}}$, M. Žujović ${ }^{2}$, V. Bogdanović ${ }^{3}$, Z. Tomić ${ }^{2}$, M. P. \\ Petrović ${ }^{2}$ \\ ${ }^{1}$ AD Mlekara - Subotica; ${ }^{2}$ Institut za stočarstvo, Beograd-Zemun; ${ }^{3}$ Poljoprivredni \\ fakultet, Zemun \\ *Corresponding author: memisin@mlekara.co.yu \\ ${ }^{* *}$ Review papers
}

\begin{abstract}
Animals require microelements in small quantities, and they play a role in virtually all physiological and biochemical processes. The role of microelements is important role from bone structure to maintaining the structure of proteins and lipids. Microelements are provided to animals in food, by special supplementation (premixes), or in water. In addition to essential minerals, which are regularly used in goat nutrition, there are 10 other elements present in traces $(\mathrm{mg} / \mathrm{kg}$ or $\mathrm{ppm})$ which are also indispensable for the goat's organism, as follows: $\mathrm{Fe}, \mathrm{J}, \mathrm{Cu}, \mathrm{Zn}, \mathrm{Mn}, \mathrm{Co}, \mathrm{Mo}, \mathrm{Se}, \mathrm{Cr}, \mathrm{F}$. In addition to these, following elements have also been identified in goats' tissues: $\mathrm{Al}, \mathrm{B}, \mathrm{Ge}, \mathrm{Cd}$, $\mathrm{As}, \mathrm{Pb}, \mathrm{Hg}, \mathrm{Ru}$, and $\mathrm{Nb}$, however their significance for the organism of goats has still not been established. Their lack in goat nutrition may to a large extent contribute to lower yields and bad health.
\end{abstract}

Key words: the goat, minerals, production traits

\section{Introduction}

Animals need microelements in small quantities, and these microelements play an important role in virtually all physiological and biochemical processes, from bone structure to maintaining the structure of proteins and lipids. Microelements are provided to animals in food, by special supplementation (premixes) or in water. In intensive production, their addition is obligatory, since this is the only way to provide them in sufficient quantities required for optimum health and production results (Memiši et al. 2004).

Minerals activate enzymes, are essential co-factors of metabolic reactions, function as carriers of proteins, regulate digestion, respiration, water balance, 
muscle reaction, nerve transmission, skeletal strength, $\mathrm{pH}$ balance, even mental balance, protect against diseases, are antagonists or synergists of other elements and play a vital role in resistance, adaptation and evolution of new breeds and strains (Lamand, 1981; Anke et Szentmihalyi, 1986; Haenlein, 1987; Kessler, 1991).

Regardless of the fact that certain microelements are present in sufficient quantities in food, subclinical or clinical signs of their deficit appear, because their availability varies, or the microelement is present in a form that can not be used. It was established that the presence of certain substances in food (phytic acid and oxalic acid), as well as interaction with other nutrients in the digestive tract influences resorption mechanisms. Resorption of microelements does not depend only on their content in food, but also on the animal's age, on electrochemical reactions in the intestine, and on the form of the microelement. Salts of minerals are most frequently used, namely oxides, carbonates, chlorides, and sulfates. Today, in addition to inorganic forms of minerals, the use of so-called "chelate" forms, i.e. organically bonded microelements is becoming more frequent.

\section{Goat requirements in Cadmium and Arsenic}

In feedmeals for goats belonging to various categories, care must be taken to satisfy a specific relationship between various minerals. The quantity of a certain mineral in food is not as important as its availability for the animal. This availability varies to a high degree, depending on numerous factors such as: their form in the food, the phase of development of plants, the presence of other minerals and components in the foods which bind them and make them unavailable, as well as the age and sex of the animal, etc. In order to prevent deficit of mineral elements in goat nutrition, there are various possibilities and certain procedures and methods to prevent this, primarily: treating fodder with various preparations, addition of elements when preparing land for fodder production, use of a premixed and complete mineral mixture in nutrition, and ultimately bodily reserves of the animal - goat can also be increased by using slow release or sustained release injections or capsules.

Research throughout the world has indicated that certain countries vary relevant to the presence of individual minerals in the soil, either as deficit or surplus, which can be used to channel and design programs to resolve the issue. Such surveys of land and plants should be linked to specific characteristics of metabolism of various animal species, and it is accepted that analysis of animal tissues is definitively the real diagnostic measure, although various tissues have different affinity for macro- and microelements, and some lack any affinity whatsoever, therefore their value as indicators differs (Table 1). Thus, the status 
or providing of Arsenic can best be tested in goats in milk or blood, while hair is one of the best indicators for the presence of this element. In addition to milk, good indicators for the presence of this microelement can also be internal organs (liver, kidneys, skeletal muscles, brain, lungs, etc.), while the heart muscle and pancreas least react to Arsenic deficit in the feedmeal (Anke et al., 1988). Content below $10 \mathrm{mcg} \mathrm{As} / \mathrm{kg} \mathrm{DM}$ of the liver, kidney or testicles in an adult goat indicates a deficit of this element in food. For kids the limit is around $25 \mathrm{mcg}$ As/kg DM.

Tabela 1. Razlike u sadržaju Arsena u tkivima koza sa izbalansiranim obrocima i onih koje su imale deficit ovog minerala u ishrani (Anke i sar., 1988).

Table 1. Significant differences As in tissue contents in goats (Anke $i$ sar., 1988).

\begin{tabular}{|c|c|c|}
\hline & $\begin{array}{l}\text { Kontrolna grupa }{ }^{1} \\
(\mathrm{n}=131) / \text { Controls }\end{array}$ & $\begin{array}{l}\text { Ogledna grupa }^{2} \\
(\mathrm{n}=113) / \mathrm{As} \\
\text { deficient }\end{array}$ \\
\hline \multicolumn{3}{|c|}{ Sadržaj As u pojedinim organima, mcg/kg SM- Organ contents, mcg As/kg DM } \\
\hline Kolostrum / Colostrum & 10 & $7,8 \mathrm{NS}$ \\
\hline Mleko / Milk & 24 & $15 * *$ \\
\hline Jetra / Liver & 25 & $4,8 * *$ \\
\hline Bubreg / Kidney & 28 & $5,8 * *$ \\
\hline Srčani mišić / Cardiac muscle & 32 & $26 \mathrm{NS}$ \\
\hline Testisi / Testicles & 14 & $3,2 * *$ \\
\hline Skeletni mišići / Skeletal muscle & 29 & $11 * *$ \\
\hline Slezina / Spleen & 41 & $12 * *$ \\
\hline Dlaka / Hair & 86 & $39 * *$ \\
\hline Mozak / Brain & 25 & $12 * *$ \\
\hline Pankreas / Pancreas & 35 & $20 \mathrm{NS}$ \\
\hline Pluća / Lungs & 27 & $16 * *$ \\
\hline
\end{tabular}

Since goats to a large extent browse on brush, shrub, and trees, as well as weeds not belonging to grasses and not studied to any greater extent, it is indispensable to know their chemical composition (Devendra, 1990). When browse from lower quality grasses is used for goat nutrition, one should keep in mind that many plants have limited value due to one or more inhibitors, that can bind, or in some other way prevent utilization of nutrients (primarily minerals) contained in them. This fact forms the basis for obligatory supplementation of minerals in the nutrition of domestic animals (goats included), which has to a large extent resulted in better milk yield, reproduction, food intake, and reduced stress due by heat and other reasons (Mc Dowell et al. 1983; Harris, 1991). 
Based on concrete experiments on goats the formulation of minerals depends to an ever decreasing degree on experiments carried out on sheep and cattle (Haenlein, 1987; Kessler, 1991) (Table 2).

Tabela 2. Donji minimum potreba koza u mikroelementima (Kessler,1991; Haenlein, 1987).

Table 2. The latest minimum mineral requirements of goats (Kessler,1991; Haenlein, 1987).

\begin{tabular}{|c|c|}
\hline $\begin{array}{l}\text { Mineralni elementi/ } \\
\text { Minerals }\end{array}$ & \\
\hline $\mathrm{Fe}$ & $30-40-100 \mathrm{mg} / \mathrm{kg} \mathrm{SM} / \mathrm{dan}-\mathrm{DM} /$ day \\
\hline $\mathbf{C u}$ & $8-10-23 \mathrm{mg} / \mathrm{kg} \mathrm{SM} / \mathrm{dan}-\mathrm{DM} / \mathrm{day}$ \\
\hline Co & $0.1-0.15 \mathrm{mg} / \mathrm{kg} \mathrm{SM} /$ dan $-\mathrm{DM} /$ day \\
\hline $\mathbf{J}$ & $0.1-0.4-0.6-0.8 \mathrm{mg} / \mathrm{kg} \mathrm{SM} / \mathrm{dan}-\mathrm{DM} / \mathrm{day}$ \\
\hline Mn & $20-40 \mathrm{mg} / \mathrm{kg} \mathrm{SM} /$ dan - DM/day \\
\hline $\mathbf{Z n}$ & $10-50 \mathrm{mg} / \mathrm{kg} \mathrm{SM} /$ dan - DM/day \\
\hline Se & $100-200 \mathrm{mcg} / \mathrm{kg} \mathrm{SM} /$ dan - DM/day \\
\hline Mo & $100 \mathrm{mcg} / \mathrm{kg} \mathrm{SM} /$ dan - DM/day \\
\hline $\mathbf{N i}$ & $300-350 \mathrm{mcg} / \mathrm{kg} \mathrm{SM} /$ dan - DM/day \\
\hline $\mathbf{V}$ & $10-25 \mathrm{mcg} / \mathrm{kg} \mathrm{SM} /$ dan - DM/day \\
\hline Cd & $50 \mathrm{mcg} / \mathrm{kg} \mathrm{SM} /$ dan - DM/day \\
\hline As & $50 \mathrm{mcg} / \mathrm{kg} \mathrm{SM} /$ dan - DM/day \\
\hline $\mathbf{L i}$ & $>2 \mathrm{mcg} / \mathrm{kg} \mathrm{SM} / \mathrm{dan}-\mathrm{DM} /$ day \\
\hline
\end{tabular}

Cadmium is an essential mineral element for goat nutrition (Anke et al., 1987b). In research by Anke et al., (1986a) during a period of 10 years, on 2 groups of goats, experimental animals (79 goats) fed fee dmeals with lower Cadmium levels (below $15 \mathrm{mcg} \mathrm{Cd} / \mathrm{kg}$ DM feed meal), compared to the control group of goats, had no significant differences in food consumption. However, the lower levels of this mineral in feed meals resulted in hindering and decreasing animal growth, decreased milk yield, shorter life span, and slower growth of kids in the suckling period which was also manifested by pronounced mortality (Table 3).

In addition, there were manifest problems of fertility and reproduction parameters in experimental goats. Conditions improved by adding $300 \mathrm{mcg}$ $\mathrm{Cd} / \mathrm{kg} \mathrm{DM}$. Symptoms of $\mathrm{Cd}$ deficit in goat nutrition are generally not expected in Europe, because research on numerous farms has shown that goats get sufficient quantities of this element in nutrition. Minimum $\mathrm{Cd}$ requirements for goats are around $50 \mathrm{mcg} / \mathrm{kg} \mathrm{DM}$ of feed meal (Anke et al., 1987b). 
Tabela 3. Efekti nedostatka Cd u ishrani koza (Anke i sar., 1986; 1987b ).

Table 3. Effects of As deficiency in goats nutrition (Anke i sar., 1986; 1987b ).

\begin{tabular}{|c|c|c|}
\hline & $\begin{array}{l}\text { Kontrolna grupa } \\
(\mathrm{n}=71) \text { / Controls } \\
\text { group }\end{array}$ & $\begin{array}{c}\text { Ogledna grupa } \\
(\mathrm{n}=79) \\
\text { / As deficient }\end{array}$ \\
\hline Koncepcija, \% / Conception rate, \% \\
\hline prvi servis / 1 st service & 73 & $46^{* *}$ \\
\hline Ukupni / Overal & 85 & $72 \mathrm{NS}$ \\
\hline Servis/koncepcija / Services/conception & 1.2 & $2,2 * *$ \\
\hline Pobačaj,\% / Abortion rate, \% & 0 & $12^{* *}(1)$ \\
\hline Veličina legla / Litter size & 1,4 & $1,6 \mathrm{NS}$ \\
\hline $\begin{array}{c}\text { Jarad/ broj odgajenih jaradi po kozi do } 91 \\
\text { dana / Kids/kidded doe at 91 days }\end{array}$ & 0,65 & $0.41^{* *}$ \\
\hline \multicolumn{2}{|c|}{ Mleko - Milk } \\
\hline Prinos mleka, kg/dan / Milk yield, kg/day & 1,01 & $0,73^{* *}$ \\
\hline Mlečna mast, \% / Fat, \% & 3,45 & $3,15^{*}$ \\
\hline Protein, \% / Protein, \% & 2,77 & $3,01 *$ \\
\hline \multicolumn{2}{|c|}{ Mortalitet - Mortality } \\
\hline Odrasle koze, \% / Adult goats, \% & 30 & $41^{*}$ \\
\hline Jarad, \% / Kids, \% & 8 & $43^{*}$ \\
\hline
\end{tabular}

(1) Tokom 4-og i 5-og meseca bremenitosti / Mostly at 4th - 5th month of pregnancy. (Anke i sar., 1986; 1987b).

Arsenic also belongs to the group of essential microelements. Research by the same group of authors during a period of 13 years (Anke et al., 1980a; 1987c), showed that nutrition containing less than $35 \mathrm{mcg}$ As/kg DM of feedmeal, did not reduce food intake in 113 experimental goats, but did result in decreased growth, mainly intrauterine and after weaning, lower conception, lower milk yield, and higher mortality, both in kids and in adult animals (Table 4). Authors state that As secretion in milk of control goats did not differ from the level in milk of goats that did not have a deficit of As in feedmeals. It is their opinion that there is an apparent blood/udder barrier that can be crossed only by high As contents in feedmeals. None of the goats with As deficit in feedmeals survived to the second lactation. Control kids formed considerably higher depots of As in their organs, especially in kidneys, than adult control goats. In addition to hair, good indicators of As availability to adult animals can be the liver, kidneys, and testicles (Anke et al., 1987c). Calculated that minimum As requirements for goats are $50 \mathrm{mcg} / \mathrm{kg}$ DM feedmeal/day, but it is considered that the majority of feeds and waters in Europe fulfill this requirement. Fish meal can be a good source of this mineral, and can contain 2 to $19 \mathrm{mcg} \mathrm{As} / \mathrm{kg} \mathrm{DM}$, followed by algae, and mussels which can contain even 10 times higher concentrations, while water sources can vary to a great extent, 
with some thermal springs that can be exceptionally rich in As (Anke, 1985; Anke et al., 1986b).

Tabela 4. Efekti nedostatka As u ishrani koza (Anke i sar., 1987c).

Table 4. Effects of As deficiency in goats (Anke i sar., 1987c)

\begin{tabular}{|l|c|c|}
\hline \multicolumn{3}{|c|}{ Koncepcija, \% / Conception rate, \% } \\
\hline Prvi servis / 1 ${ }^{\text {st }}$ servis & 75 & $57^{* *}$ \\
\hline Ukupni / overall & 89 & $71^{* *}$ \\
\hline $\begin{array}{l}\text { Jalova (ne koncipira) / open (not } \\
\text { conceiving) }\end{array}$ & 11 & $29 * *$ \\
\hline Servis/koncepcija / Services/conception & 1,3 & $1,9^{* *}$ \\
\hline Pobačaj,\% / Abortion rate \% & 0,8 & $15^{* *(1)}$ \\
\hline Veličina legla / Litter size & 1,4 & $1,4 \mathrm{NS}$ \\
\hline $\begin{array}{l}\text { Broj odgajenih jaradi po kozi do 91 dana / } \\
\text { Kids/kidded doe at 91 days }\end{array}$ & 0,73 & $0,48^{* *}$ \\
\hline Odnos polova Ž : M / Sex ratio F:M & $1: 1,6$ & $1: 1,7 \mathrm{NS}$ \\
\hline \multicolumn{2}{|c|}{ Mleko / Milk } \\
\hline Prinos mleka, kg/dan / Yield, kg/day & 1.01 & $0.81 * *$ \\
\hline Mlečna mast, \% / Fat \% & 3.46 & $3.97 *$ \\
\hline Protein, \% / Protein, \% & 2.77 \\
\hline \multicolumn{2}{|c|}{ Mortalitet / Mortality } \\
\hline Odrasle koze, \% / Adult goats, \% & 24 \\
\hline Jarad, \% / Kids, \% & 5.8 \\
\hline
\end{tabular}

(1) Odrasle koze / Adult goats;

\section{Conclusion}

High production and milk yield in goats require also more macro- and microelements, and increase needs. Their adequate balancing in feed meals for goats is more difficult due to the specific nutrition of goats, i.e. due to the use of feeds with insufficiently studied nutritive value. $\mathrm{Cd}$ and As deficit in nutrition of offspring and adult goats can have an unfavorable effect on growth, but can also decrease yield, and may cause health problems. Therefore, adequate goat nutrition requires maximum balancing of all nutrients in feed meals, which is achieved by using various feeds and mineral premixes. 


\title{
Uticaj zastupljenosti kadmijuma i arsena u obroku na proizvodne i reproduktivne osobine koza
}

\author{
N. Memiši, M. Žujović, V. Bogdanović, Z. Tomić, M. P. Petrović,
}

\section{Rezime}

Mikroelementi su životinjama potrebni u malim količinama i učestvuju u skoro svim fiziološkim i biohemijskim procesima. Počev od strukture kostiju pa do održavanja strukture proteina i lipida, mikroelementi igraju važnu ulogu. Obezbeđenje životinja sa mikroelementima obavlja se putem hrane, posebnim dodavanjem (putem predsmeša) ili putem vode. U intenzivnoj proizvodnji njihovo dodavanje je obavezno, jer se samo tako mogu obezbediti u dovoljnim količinama za optimalno zdravstveno stanje i proizvodne rezultate. Osim esencijalnih minerala, koji se redovno koriste u ishrani koza, postoji još 10 elemenata prisutnih $\mathrm{u}$ tragovima $(\mathrm{mg} / \mathrm{kg}$ ili $\mathrm{ppm})$ koji su takođe, neophodni za organizam koza, a to su: $\mathrm{Fe}, \mathrm{J}, \mathrm{Cu}, \mathrm{Zn}, \mathrm{Mn}, \mathrm{Co}, \mathrm{Mo}, \mathrm{Se}, \mathrm{Cr}, \mathrm{F}$. Pored navedenih, u tkivima koza identifikovani su još i: Al, $\mathrm{B}, \mathrm{Ge}, \mathrm{Cd}, \mathrm{As}, \mathrm{Pb}, \mathrm{Hg}, \mathrm{Ru}$, i Nb, za koje još nije utvrđeno u kojoj su meri neophodni u organizmu koza. Njihov nedostatak u ishrani koza u velikoj meri može doprineti nižoj proizvodnji i lošem zdravstvenom stanju.

Ključne reči: koza, minerali, proizvodne osobine

\section{Literatura}

ANKE, M., GROPPEL, B., KRAUSE, U., ANGELOW, L., REGIUS, A., MASAOKA, T., KOSLA, T. and LANGER, M. 1988. Diagnostic possibilities of the status of zinc, manganese, copper, iodine, selenium, molybdenum, cadmium, nickel, lithium and arsenic. Proc. Macro- and Trace Element Seminar, University Leipzig-Jena, Germany, Dec. 20-21, 368.

ANKE, M. and SZENTMIHALYI, S. 1986. Principles of supply and metabolism of trace elements in ruminants. Proc. Macro- and Trace Element Seminar, University Leipzig-Jena, Germany, Dec. 1-2, 87.

ANKE, M., GROPPEL, B., SCHMIDT, A. and KRONEMANN, H. (1986a): Cadmium deficiency in ruminants. Proc. $5^{\text {th }}$ Intern. Trace Element Symposium, University Leipzig-Jena, Germany, July 14-17, 937. 
ANKE, M., GROPPEL, B. and SCHMIDT, A. (1987b): New results on the essentiality of cadmium in ruminants. Proc. Symposium Trace Subst. in Environm. Health XXI., Univ. Missouri, Columbia, MO, USA, 556.

ANKE, M., KRAUSE, U. and GROPPEL, B. 1987c. The effect of arsenic deficiency on growth, reproduction, life expectancy and disease symptoms in animals. Proc. Symposium Trace Subst. in Environm. Health XXI., University Missouri, Columbia, MO, USA, 533.

ANKE, M., GROPPEL, B., GRUEN, M., HENNIG, A. and MEISSNER, D. (1980a): The influence of arsenic deficiency on growth, reproductiveness, life expectancy and health of goats. Proc. $3^{\text {rd }}$ Intern. Trace Element Symposium, University Leipzig-Jena, Germany, July 7$11,25$.

DEVENDRA, C. (ed.) 1990. Shrubs and tree fodders for farm animals. Proc. Intern. Dev. Res. Ctr. Workshop, Denpasar, Indonesia, July 24-29, pp. 349. FRIDA BAUMAN, MEMIŠI, N., GRUBIĆ, G. (2003): Ishrana priplodnih jarčeva. Poljoprivredne aktuelnosti, br 1-2, str. 99-106, Beograd.

HAENLEIN, G.F.W. 1987. Mineral and vitamin requirements and deficiencies. Proc. IVth Intern. Conf. Goats, Brasilia, Brazil, March 8-13, 1249.

HARRIS, B.Jr. 1991. Extra minerals may increase milk production. Lancaster Farming, 7/6:D2.

INRA (1978): INRA. (1978): Alimentation des Ruminants. INRA Publications, Versailles. Itovic (1979): Elevage des jenes caprins. Speoc 127 p.

KESSLER, J. 1991. Mineral nutrition of goats. In: P. Morand-Fehr (ed.), Goat Nutrition, Pudoc Publ., Wageningen, Netherlands, EAAP Publ. No. 46, 104.

LAMAND, M. 1981. Metabolism and requirements of microelements by goats. Proc. ITOVIC-INRA Intern. Symposium Nutrition Systems Goat Feeding, Tours, France, May 12-15, I:210.

McDOWELL, L.R., Conrad, J.H. and Ellis, G.L. 1983. Mineral deficiencies, imbalances and diagnosis I, II. Feedstuffs, 9/12:31-39; 9/19:21.

MEMIŠI, N., FRIDA BAUMAN (2002) Koza. Poljoprivredna biblioteka. Beograd.

MEMIŠI, N., FRIDA BAUMAN (2003a): Ishrana koza u periodu bremenitosti. Poljoprivredne aktuelnosti, br 1-2, str. 75-86, Beograd.

MEMIŠI, N., FRIDA BAUMAN (2003b): Ishrana koza u laktacionom periodu. Poljoprivredne aktuelnosti, br 1-2, str. 87-98, Beograd.

MEMIŠI, N., FRIDA BAUMAN, BISERKA PAVLOV (2003): The effect of nutrition of kids in fattening on dressing percentage and meat quality. The second joint of Departments of Animal Science of the Balkan countries BALNIMALCON-2003, October 15-17, Bucharest - Romania.

MEMIŠI, N., FRIDA BAUMAN (2003c): Sistemi odgoja i ishrane jaradi u dojnom periodu. Poljoprivredne aktuelnosti, br 3-4, str. 87-96, Beograd. 
MEMIŠI, N., FRIDA BAUMAN (2003d): Ishrana rano odlučene jaradi. Poljoprivredne aktuelnosti, br 3-4, str. 97-102, Beograd.

MEMIŠI, N., FRIDA BAUMAN, GRUBIĆ, G., JOVANOVIĆ, S., BISERKA PAVLOV, (2003e): Effect of weaning time of kids on their health status and achieved growth rate. II Symposium of livestock production with international participation, June $18-21$, Ohrid.

MEMIŠI, N., FRIDA BAUMAN, MEKIĆ, C., BOGDANOVIĆ, V. (2004): Značaj mineralne ishrane za proizvodnju i zdravstveno stanje koza. XVI Inovacije u stočarstvu. Biotehnologija u stočarstvu 18 (5-6) p 81-85, Beograd. MEMIŠI, N., FRIDA BAUMAN (2007): Ishrana koza. Admiralbook. Beograd. NRC, 1981. Nutrient requirements of goats: Angora, dairy and meat goats in temperate and tropical countries. Nat. Academy Sci., Washington, D.C., pp. 91. 